\title{
Kinerja Pejabat Pembuat Akta Tanah Sementara Dalam Pengelolaan Bea Perolehan (BPHTB) di Kabupaten Indramayu
}

\author{
Komir Bastaman \\ Universitas Subang \\ Komirbastaman60@gmail.com
}

\begin{abstract}
This study examines and analyzes the Performance of Temporary Land Deed Makers (PPATS) in the Management of Land or Building Acquisition Fees (BPHTB) in Sukra District, Indramayu Regency. The research approach used is a qualitative approach that is a research procedure that describes the facts and explains the object of research as well as digging the information needed in accordance with reality as it is. The results of the study illustrate that first The quality of PPATS officials especially in Sukra District in managing BPHTB is still not optimal, it can be seen from the realization that has not reached the target set by the Regional Government in accordance with the existing potential, even for the 2015 target it fell from the realization to previous year; second Quantity of results of work carried out by PPATS Officers in managing BPHTB in the Sukra District area is still not effective because the results achieved are not in accordance with the targets set by the regional government in terms of the potential that exists in the Sukra District area; third The use of time carried out by PPATS Officers in Sukra District in accordance with working hours ie from Monday to Friday Collection of BPHTB is carried out after there is a sale and purchase transaction of land and / or building and a deed of sale and purchase (AJB) conducted by PPATS Officials; fourt Cooperation of PPATS Officials in Sukra District with the community is already good, it's just that there are still many people who are not aware of the benefits of Tax, that is because the level of public education in Sukra District is still low on average plus the level of taxpayer knowledge that is still lacking.
\end{abstract}

Keywords: performance, governance, tax, bphtb

\begin{abstract}
Abstrak
Penelitian ini mengkaji dan menganalisis mengenai Kinerja Pejabat Pembuat Akta Tanah Sementara (PPATS) dalam Pengelolaan Bea Perolehan Atas Tanah Atau Bangunan (BPHTB) di Kecamatan Sukra Kabupaten Indramayu. Pendekatan penelitian yang digunakan adalah pendekatan kualitatif yaitu prosedur penelitian yang menggambarkan fakta-fakta dan menjelaskan objek penelitian serta menggali informasi
\end{abstract}


yang dibuthkan sesuai dengan kenyataan sebagaimana adanya. Hasil penelitian memberikan gambaran bahwa pertama Kualitas Pejabat PPATS khususnya di Kecamatan Sukra dalam pengelolaan BPHTB masih kurang maksimal, itu terlihat dari realisasi yang belum mencapai target yang sudah ditentukan oleh Pemerintah Daerah sesuai dengan potensi yang ada, bahkan untuk target tahun 2015 turun dari realisasi untuk tahun sebelumnya; kedua Kuantitas hasil pekerjaan yang dilaksanakan oleh Pejabat PPATS dalam mengelola BPHTB di wilayah Kecamatan Sukra masih belum efektif karena hasil yang dicapai tersebut belum sesuai target yang telah ditetapkan oleh pemerintah daerah dilihat dari potensi yang ada di wilayah Kecamatan Sukra; ketiga Penggunaan waktu yang dilaksanakan oleh Pejabat PPATS di Kecamatan Sukra sesuai dengan jam kerja yaitu dari hari Senin sampai dengan Jum'at. Pemungutan BPHTB dilaksanakan setelah ada transaksi jual beli tanah dan/atau bangunan dan melakukan akta jual beli (AJB) yang dilakukan oleh Pejabat PPATS; ke-empat Kerjasama Pejabat PPATS di Kecamatan Sukra dengan masyarakat sudah baik, hanya saja masih banyak masyarakat belum menyadari manfaat Pajak, itu dikarenakan tingkat pendidikan masyarakat di Kecamatan Sukra rata-rata masih rendah ditambah lagi tingkat pengetahuan wajib pajak yang masih kurang.

Kata Kunci: kinerja, pengelolaan, pajak, bphtb

\section{Pendahuluan}

Pajak daerah merupakan sumber pendapatan yang penting guna membiayai penyelenggaraan pemerintahan dan pembangunan daerah untuk mendukung pelaksanaan otonomi daerah yang nyata, luas, dinamis dan bertanggung jawab sebagaimana diamanatkan di dalam Undang- Undang Republik Indonesia Nomor 23 Tahun 2014 Tentang Pemerintahan Daerah. Otonomi daerah merupakan suatu konsekuensi reformasi yang harus dihadapi oleh seluruh daerah di Indonesia. Oleh karena itu dibutuhkan pembelajaran disetiap daerah untuk dapat mengubah tantangan menjadi sebuah peluang bagi kemajuan daerahnya. Disisi lain, pemerintah sebagai pengatur pengembangan konsep otonomi daerah, berperan sebagai penanggung jawab agar konsep otonomi daerah dapat dilaksanakan seperti yang diharapkan. Daerah otonom diharapkan mampu untuk mengurus dan mengatur rumah tangganya sendiri melalui sumber pendapatan yang dimiliki. Hal ini meliputi semua kekayaan yang dikuasai oleh daerah dengan batas-batas kewenangan yang ada dan selanjutnya digunakan untuk membiayai semua kebutuhan dalam rangka penyelenggaraan urusan rumah tangga. Otonomi daerah juga diharapkan mampu mendorong perbaikan pengelolaan sumber daya yang dimiliki oleh setiap daerah. Kemampuan daerah dalam menjalankan pemerintahan daerah sangat bergantung pada kemampuan 
pendanaannya. Daerah selalu merasa sumber dana yang dimilikinya kurang memadai dan pemerintah pusat dituduh enggan berbagai pendapatan dengan daerah. Untuk itu, perlu dipahami terlebih dahulu berbagai jenis sumber pendapatan daerah. Dalam beberapa waktu terakhir, banyak pemda yang semakin tergantung kepada dana atau bantuan kiriman pemerintah pusat atau provinsi. Dengan adanya kebijakan otonomi daerah ini diharapakan kepada pemerintah daerah yang bersangkutan dapat mengatur dan mengurus rumah tangganya sendiri serta untuk meningkatkan daya guna penyelenggaran pemerintah daerah dalam rangka pelayanan terhadap masyarakat dan pelaksanaan pembangunan. Otonomi Daerah juga diharapkan mampu mendorong perbaikan pengelolaan sumber daya yang dimiliki setiap daerah. Otonomi Daerah memiliki implikasi yang luas pada kewenangan daerah untuk menggali dan mengelola sumber-sumber pendapatan daerah dalam rangka pembangunan dan kesejahteraan masyarakat di daerah. Seiring dengan berjalannya waktu, timbul masalah dalam otonomi daerah. Perkembangan dan pembangunan daerah menjadi tidak merata. Banyak daerah yang merasa sumber dana yang dimilikinya kurang memadai dan pemerintah pusat dianggap kurang mau berbagi. Untuk itu perlu adanya kebijakan untuk meningkatkan penerimaan daerah, salah satunya dengan mengalihkan pajak yang sebelumnya merupakan tanggung jawab pemerintah pusat.

Pajak merupakan kontribusi wajib kepada negara yang terutang oleh orang pribadi atau badan yang bersifat memaksa berdasarkan Undang-undang, dengan tidak mendapat timbal balik secara langsung dan digunakan untuk keperluan negara bagi sebesar-besarnya kemakmuran rakyat (Pasal 1 angka 1 Undang-Undang Nomor 6 Tahun 1983 sebagaimana telah disempurnakan terakhir dengan Undang-Undang Nomor 28 Tahun 2007). Pajak yang dipungut dari masyarakat sesuai ketentuan akan dikembalikan kepada masyarakat oleh pemerintah dalam bentuk penyediaan sarana dan prasarana, menyediakan lapangan kerja, memberikan rasa aman dan lainnya yang termasuk pengeluaran umum. Pajak dikenakan kepada orang pribadi atau badan yang memiliki penghasilan dan dikenakan atas setiap transaksi penjualan tidak terkecuali transaksi jual beli tanah atau transaksi pengalihan hak yang mengakibatkan diperolehnya hak atas tanah dan bangunan yang biasanya disebut sebagai Bea Perolehan Hak atas Tanah dan Bangunan (BPHTB).

Bea Perolehan Hak atas Tanah dan Bangunan (BPHTB) adalah pajak yang dikenakan atas perolehan hak atas tanah dan bangunan. Sesuai dengan UndangUndang Nomor 21 Tahun 1997 tentang BPHTB yang telah diubah dengan Undangundang Nomor 20 tahun 2000 tentang Bea Perolehan Hak atas Tanah dan Bangunan menjelaskan bahwa BPHTB tergolong sebagai pajak pusat dimana penerimaannya akan dikategorikan sebagai dana bagi hasil. Dana bagi hasil pajak itu sendiri termasuk dalam bagian dana perimbangan yang diterima oleh pendapatan daerah. Alokasi dana bagi hasil BPHTB ditetapkan berdasarkan rencana penerimaan BPHTB tahun anggaran yang bersangkutan dan ditetapkan oleh Menteri Keuangan paling lambat sebelum anggaran bersangkutan dilaksanakan. Adapun penerimaan negara dari BPHTB adalah dibagi 
dengan imbangan $20 \%$ untuk pemerintah pusat dan $80 \%$ untuk pemerintahan daerah. Dari $80 \%$ untuk daerah akan dibagi lagi menjadi 16\% untuk daerah provinsi yang bersangkutan, dan $64 \%$ untuk daerah kabupaten/kota penghasil. Namun dengan diberlakukannya Undang-Undang Nomor 28 Tahun 2009 tentang Pajak Daerah dan Retribusi Daerah, Pajak BPHTB resmi dijadikan sebagai pajak daerah. Masa transisi pengalihan BPHTB ditetapkan selama 1 (satu) tahun sejak berlakunya Undang-Undang Nomor 28 tahun 2009 tersebut dan mulai efektif menjadi pajak daerah pada tanggal 1 Januari 2011. Dimana dengan adanya pengalihan tersebut, BPHTB dipercaya sebagai sumber pendapatan asli daerah yang memiliki potensi sangat besar.

Kabupaten Indramayu sudah menerbitkan Peraturan Daerah Kabupaten Indramayu Nomor 18 Tahun 2010 tentang Bea Perolehan Hak Atas Tanah dan Bangunan Kabupaten Indramayu. Menurut Pasal 3 Peraturan Daerah Kabupaten Indramayu Nomor 18 Tahun 2010 adalah Subjek Pajak Bea Perolehan Hak atas Tanah dan Bangunan adalah orang pribadi atau Badan yang memperoleh Hak atas Tanah dan/atau Bangunan. Wajib Pajak Bea Perolehan Hak atas Tanah dan Bangunan adalah orang pribadi atau badan yang memperoleh hak atas Tanah dan / atau Bangunan. Pemerintah Kabupaten Indramayu dalam hal ini Dinas Pendapatan, Pengelolaan Keuangan Dan Aset Daerah Kabupaten Indramayu mencatat bahwa dalam pendapatan pajak BPHTB Kecamatan Sukara pada tahun 2013 sampai 2017 tidak tercapai target. Salah satu ukuran keberhasilan pemungutan pajak BPHTB adalah dengan cara menghitung efektivitas pemungutan pajak BPHTB, dapat dilihat pada tabel sebagai berikut:

Tabel 1.

Data Penerimaan BPHTB di Kecamatan Sukra Kabupaten Indramayu Tahun 2013 s.d 2017

\begin{tabular}{|l|c|c|c|c|c|}
\hline No & Tahun & $\begin{array}{c}\text { Wajib Pajak Yang } \\
\text { Melakukan } \\
\text { Peralihan Hak }\end{array}$ & $\begin{array}{c}\text { Yang } \\
\text { Bayar }\end{array}$ & $\begin{array}{c}\text { Yang } \\
\text { Tidak } \\
\text { Bayar }\end{array}$ & Persentase \\
\hline 1 & 2013 & 538 & 25 & 513 & 4.65 \\
\hline 2 & 2014 & 627 & 29 & 598 & 4.63 \\
\hline 3 & 2015 & 533 & 19 & 514 & 3.56 \\
\hline 4 & 2016 & 478 & 54 & 424 & 11.30 \\
\hline 5 & 2017 & 592 & 89 & 503 & 15.03 \\
\hline
\end{tabular}

Sumber : Kantor Kecamatan Sukra Kabupaten Indramayu, 2018

Realisasi penerimaan pajak BPHTB tidak mencapai target yang ditetapkan pada tahun 2013 dan 2017. Pertumbuhan penerimaan pajak BPHTB cenderung berfluktuatif. Peningkatan pajak BPHTB dari tahun ketahun, yang dihitung dari realisasi jumlah penerimaan belum dapat dijadikan ukuran keberhasilan pemungutan pajak yang telah 
dilakukan oleh pemerintah Kecamatan Sukra Kabupaten Indramayu. Jika dilihat dari sisi pengelolaannya, BPHTB di Kecamatan Sukra ini belum sepenuhnya optimal karena dalam pelaksanaannya masih mengalami hambatan-hambatan yang cukup signifikan baik dalam pemungutannya maupun dalam administrasi pengelolaannya. Terhambatnya penerimaan BPHTB sedikit banyak akan menghambat kelancaran pelaksanaan pembangunan, oleh karena itu agar pembangunan tidak terhambat maka upaya peningkatan penerimaan BPHTB harus terus dipacu dan ditingkatkan oleh semua aparat pemungut BPHTB.

Kinerja adalah hasil atau tingkat keberhasilan seseorang secara keseluruhan selama periode tertentu dalam melaksanakan tugas, seperti standar hasil kerja, target atau sasaran atau kriteria yang ditentukan terlebih dahulu telah disepakati bersama (Siagian, 2006 : 34). Kinerja sebagai suatu keseluruhan kemampuan untuk bekerja sedemikian rupa sehingga mencapai tujuan kerja secara optimal dan berbagai sasaran yang telah diciptakan dengan pengorbanan yang secara rasio lebih kecil dibandingkan dengan hasil yang dicapai. Kinerja Pejabat Pembuat Akta Tanah Sementara (PPATS) sangatlah memprihatinkan, karena kurangnya pengertian masyarakat akan kewajibannya membayar Pajak BPHTB. Karena kurangnya penyuluhan dari aparat yang berwenang juga tingkat intelektual masyarakat pedesaan yang minim, tidak mempunyai kesadaran dalam membayar Pajak BPHTB. Karena kemiskinan dan pelaksanaan pemungutan itu sendiri yang juga banyak menemui hambatan yang disebabkan kurangnya kesadaran para aparat berwenang dalam kewajibannya untuk melakukan pemungutan pajak.

Dari uraian di atas dapat dilihat banyak kendala dalam pelaksanaan pemungutan BPHTB di Kecamatan Sukra tersebut. Untuk itu di Kecamatan Sukra, perlu untuk dilaksanakannya suatu tinjauan tentang kinerja PPATS dalam pemungutan BPHTB di Kecamatan Sukra. Karena di Kecamatan Sukra pemungutan Pajak BPHTB dilakukan oleh PPATS, dalam hal ini adalah PPATS yang diberi wewenang memungut pajak dari masyarakat yang ada dibawahnya. Dari hasil penelitian penulis menemukan bahwa Kinerja PPATS Kecamatan Sukra dalam pengelolaan BPHTB belum optimal dengan permasalahan sebagai berikut : pertama, Wajib Pajak tidak mau untuk membayar Pajak BPHTB pada waktu transaksi akte jual beli atau peralihan hak atas tanah atau bangunan, data tahun 2018 dari total 592 wajib pajak yang melakukan peralihan hak, yang membayar hanya $15.03 \%$; kedua: Wajib pajak yang melakukan peralihan hak sekitar 65\% tidak memiliki kartu NPWP sehingga mengalami kesulitan dalam pembayaran BPHTB nya; dan ketiga : kurangnya sosialisasi tata cara pelayanan BPHTB oleh pihak kecamatan.

\section{Kerangka Teori}

\section{Pengertian Kinerja}

Kinerja (performance) sudah menjadi kata popular yang sangat menarik dalam pembicaraan manajemen publik. Konsep kinerja pada dasarnya dapat dilihat dari dua 
segi, yaitu kinerja pegawai (per-individu) dan kinerja organisasi. Kinerja adalah gambaran mengenai tingkat pencapaian pelaksanaan tugas dalam suatu organisasi, dalam upaya mewujudkan sasaran, tujuan, misi, dan visi organisasi tersebut (Bastian, 2001:329). Konsep kinerja (Performance) dapat didefinisikan sebagai sebuah pencapaian hasil atau degree of accomplishtment (Rue dan byars, 1981 dalam Keban 2005 : 59). Hal ini berarti bahwa, kinerja suatu organisasi itu dapat dilihat dari tingkatan sejauh mana organisasi dapat mencapai tujuan yang didasarkan pada tujuan yang sudah ditetapkan sebelumnya. Kinerja merupakan hasil dari kegiatan kerjasama diantara anggota atau komponen organisasi dalam rangka mewujudkan tujuan organisasi. Sederhananya, kinerja merupakan produk dari kegiatan administrasi, yaitu kegiatan kerjasama dalam sebuah organisasi atau kelompok untuk mencapai tujuan yang pengelolaannya biasa disebut sebagai manajemen.

Kinerja dikatakan sebagai sebuah hasil (output) dari suatu proses tertentu yang dilakukan oleh seluruh komponen organisasi terhadap sumber-sumber tertentu yang digunakan (input). Selanjutnya, kinerja juga merupakan hasil dari serangkaian proses kegiatan yang dilakukan untuk mencapai tujuan tertentu organisasi. Dalam kerangka organisasi terdapat hubungan antara kinerja perorangan (individual Performance) dengan kinerja organisasi (Organization Performance). Organisasi pemerintah maupun swasta besar maupun kecil dalam mencapai tujuan yang telah ditetapkan harus melalui kegiatan-kegiatan yang digerakkan oleh orang atau sekelompok orang yang aktif berperan sebagai pelaku, dengan kata lain tercapainya tujuan organisasi hanya dimungkinkan karena adanya upaya yang dilakukan oleh orang dalam organisasi tersebut.

Kinerja merupakan suatu fungsi dari motivasi dan kemampuan untuk menyelesaikan tugas atau pekerjaan. Seseorang sepatutnya memiliki derajat kesediaan dan tingkat kemampuan tertentu. Kesediaan dan keterampilan seseorang tidaklah cukup efektif untuk mengerjakan sesuatu tanpa pemahaman yang jelas tentang apa yang akan dikerjakan dan bagaimana mengerjakan. Pernyataan Smith yang dikutip oleh Sedarmayanti (2001 : 50), mengungkapkan bahwa kinerja adalah :"Ouput drive from process, human or otherwise (Kinerja merupakan hasil atau keluaran dari suatu proses)." Sedangkan menurut Effendy (2002 : 194) "Kinerja adalah unjuk kerja yang merupakan hasil kerja dihasilkan oleh pegawai atau prilaku nyata yang ditampilkan sesuai dengan perannya dalam organisasi."

Kinerja merupakan hasil dan keluaran yang dihasilkan oleh seorang pegawai sesuai dengan perannya dalam organisasi dalam suatu periode tertentu. Kinerja pegawai yang baik adalah salah satu faktor yang sangat penting dalam upaya instansi untuk meningkatan produktivitas. Kinerja merupakan indikator dalam menentukan bagaimana usaha untuk mencapai tingkat produktivitas yang tinggi dalam suatu organisasi atau instansi. Berdasarkan definisi kinerja di atas menjelaskan gambaran mengenai tingkat pencapaian pelaksanaan tugas yang dilakukan oleh seluruh pegawai yang ada disuatu organisasi atau instansi pemerintah(Hikmawan \& Hidayat, 2016). Meningkatkan kinerja dalam sebuah organisasi atau instansi pemerintah merupakan 
tujuan atau target yang ingin dicapai oleh organisasi dan instansi pemerintah dalam memaksimalkan suatu kegiatan.

\section{Manajemen Kinerja}

Manajemen kinerja adalah suatu proses strategis dan terpadu yang menunjang keberhasilan organisasi melalui pengembangan performansi SDM. Dalam manajemen kinerja kemampuan SDM sebagai kontributor individu dan bagian dari kelompok dikembangkan melalui proses bersama antara manajer dan individu yang lebih berdasarkan kesepakatan daripada instruksi. Kesepakatan ini meliputi (objectivies), persyaratan pengetahuan, keterampilan dan kemampuan, serta pengembangan kinerja dan perencanaan pengembangan pribadi.

Ditinjau dari bunyi kalimatnya, manajemen kinerja ini berkaitan dengan usaha, kegiatan atau program yang diprakarsai dan dilaksanakan oleh pimpinan organisasi (perusahaan) untuk "merencanakan, mengarahkan dan mengendalikan prestasi pegawai". Karena program ini mencantumkan kata management, seluruh yang dilakukan dalam sebuah proses manajemen harus terjadi, yakni dimulai dari menetapkan tujuan yang ingin dicapai, pembuatan rencana, pengorganisasian, penggerakan/pengarahan dan akhirnya evaluasi atas hasilnya. Secara teknis program ini harus dimulai dengan menetapkan tujuan dan sasaran yaitu "kinerja dalam bentuk apa dan yang seperti bagaimana yang ingin dicapai". Karena yang menjadi obyek adalah kinerja manusia, maka bentuk yang paling umum tentunya adalah kinerja dalam bentuk "produktivitas" sumber daya manusia (Ruky, 2001).

Dari berbagai pendapat para ahli tersebut di atas dapat disimpulkan bahwa dimensi pengukuran kinerja sangat beragam tergantung dari aspek tertentu yang diukur (atribut atau kompetensi individunya, kinerja individu), kualitas dan kuantitas produk yang dihasilkan (kinerja hasil), kinerja pegawai ataupun kinerja proses dan cara pengukurannya.

\section{Metode Penelitian}

Penelitian ini menggunakan metode penelitian deskriptif dengan pendekatan kualitatif. Penelitian kualitatif bertujuan untuk menggambarkan secara tepat sifat-sifat individu, keadaan, gejala atau kelompok tertentu untuk menentukan adanya suatu gejala dengan gejala lain dalam masyarakat. Penelitian kualitatif sebagai prosedur penelitian yang menghasilkan data deskriptif berupa kata-kata tertulis atau lisan dari orang-orang dalam perilaku yang dapat diamati (Hikmawan, 2017). Metode yang digunakan dalam penelitian ini bertujuan untuk mendapatkan data-data berdasarkan keadaan yang ada, hasil wawancara langsung dengan informan dan dari dokumendokumen yang ada (Bogdan dan Taylor dalam Moleong, 2005 : 3). Penggunaan metode deskriptif dengan pendekatan kualitatif ini memiliki keunggulan karena masalah yang dikaji tidak sekedar berdasarkan laporan pada suatu kejadian atau fenomena saja melainkan juga dikonfirmasi dengan sumber-sumber lain yang relevan. Berdasarkan tujuan penelitian kualitatif, maka prosedur sampling yang penting adalah bagaimana 
menemukan informasi kunci (key informant). Orientasi mengenai informan adalah bukan berapa jumlah masyarakat yang dijadikan informan tetapi apakah data yang terkumpul sudah mencukupi atau belum.

Metode penelitian kualitatif digunakan dalam penelitian ini, karena pada umumnya permasalahannya belum jelas, holistik, dinamis, dan penuh makna sehingga tidak mungkin data pada situasi sosial tersebut diperoleh dengan metode penelitian kuantitatif dengan instrumen seperti test, kuesioner. Selain itu peneliti bermaksud memahami situasi sosial secara mendalam, menemukan pola, hipotesis dan teori (Sugiyono, 2010 : 399).

Penjelasan diatas dapat disimpulkan bahwa penelitian deskriptif dengan Penelitian deskriptif dengan pendekatan kualitatif mempunyai karakteristik antara lain: berlatar belakang alamiah, mengandalkan manusia sebagai obyek penelitian(Hikmawan, 2014), memanfaatkan data kualitatif, menggunakan analisis secara induktif, mengarahkan sasaran penelitian pada usaha menemukan teori dasar yang bersifat deskriptif, lebih mementingkan pada hasil, membatasi kajian pada fokus tertentu, rancangan penelitiannya bersifat sementara, dan hasil penelitiannya dapat diterima oleh semua pihak. Sehingga bentuk ini dirasa penting dalam penelitian ini. Penelitian kualitatif tidak dimaksudkan untuk membuat generalisasi dari hasil penelitiannya. Menurut Suyanto (2005:171) pada penelitian kualitatif tidak dikenal adanya populasi. Subjek penelitian ini menjadi informan yang akan memberikan berbagai informasi yang diperlukan selama proses penelitian. Informan adalah seseorang yang benar-benar mengetahui suatu persoalan atau permasalahan tertentu yang darinya dapat diperoleh informasi yang jelas, akurat, dan terpercaya baik berupa pernyataan, keterangan, atau data-data yang dapat membantu dalam memahami persoalan atau permasalahan tersebut (Widiyanto, Hikmawan, \& Riswanda, 2019).

Menurut Suyanto (2005:172) informan penelitian meliputi beberapa macam, yaitu Informan Kunci (Key Informan) merupakan mereka yang mengetahui dan memiliki berbagai informasi pokok yang diperlukan dalam penelitian, 2) Informan Utama merupakan mereka yang terlibat langsung dalam interaksi sosial yang diteliti, 3) Informan Tambahan merupakan mereka yang dapat memberikan informasi walaupun tidak langsung terlibat dalam interaksi sosial yang diteliti.

Dalam penelitian ini, penulis menggunakan informan kunci dan informan utama. Informan di sini adalah yang dapat memberikan informasi mengenai Kinerja Pejabat Pembuat Akta Tanah Sementara (PPATS) dalam Pengelolaan Bea Perolehan Atas Tanah Atau Bangunan (BPHTB) di Kecamatan Sukra Kabupaten Indramayu, maka penulis menunjuk informan sebagai berikut:

1. Informan Kunci (Key Informan) adalah Camat Kecamatan Sukra Kabupaten Indramayu, karena Camat adalah pejabat Pembuat Akta Tanah Sementara (PPATS) Kecamatan Sukra.

2. Sedangkan informan utama adalah :

a. Sekretaris Kecamatan Sukra, karena salah satu tugasnya adalah pelaksana pengelola BPHTB. 
b. Petugas Pembuat Akta Tanah Sementara (PPATS) Kecamatan Sukra, karena petugas tersebut merupakan pelaksana yang tahu persis permasalahan yang ada di lapangan

c. Perwakilan wajib pajak masyarakat di wilayah Kecamatan Sukra.

\section{Hasil dan Diskusi}

\section{Kualitas dalam Penerimaan Pajak}

Pajak adalah salah satu sumber penerimaan negara yang sangat penting bagi penyelenggaraan pemerintahan dan pelaksanaan pembangunan nasional. UndangUndang Dasar 1945 telah menempatkan kewajiban perpajakan sebagai salah satu perwujudan kewajiban kenegaraan dan sebagai sarana peran serta dalam pembiayaan negara dan pembangunan nasional untuk mencapai masyarakat adil dan makmur. Pasal 33 ayat (3) amandemen Undang-Undang Dasar 1945 menyatakan bahwa bumi dan air, dan kekayaan alam yang terkandung di dalamnya dikuasai oleh negara dan dipergunakan untuk sebesar-besarnya kemakmuran rakyat. Bumi sebagai contoh Tanah merupakan karunia Tuhan Yang Maha Kuasa mempunyai fungsi sosial, kepentingan lainnya untuk memenuhi kebutuhan dasar, lahan usaha atau alat investasi yang menguntungkan. Di atas tanah terletak bangunan yang juga memberikan manfaat ekonomi kepada pemilik. Maka sudah sewajarnya bila pemilik atau yang memperoleh Hak atas Tanah dan Bangunan menyerahkan sebagian nilai ekonomis yang diperolehnya kepada pemerintah melalui pembayaran pajak yang di sebut Bea Perolehan Hak atas Tanah dan Bangunan (BPHTB).

BPHTB dahulunya merupakan Pajak Pusat, yang diatur dalam Undang-Undang Nomor 21 Tahun 1997 tentang Bea Perolehan Hak atas Tanah dan Bangunan yang telah diubah dengan Undang-Undang Nomor 20 Tahun 2000. Kemudian pada September 2009, Presiden atas persetujuan DPR telah mengesahkan Undang-Undang Nomor 28 Tahun 2009 tentang Pajak Daerah dan Retribusi Daerah, yang mulai berlaku pada tanggal 1 Januari 2010. Bagian Ketujuh Belas mengatur khusus tentang BРHTB, ВРНTB dialihkan sebagai pajak daerah dalam waktu paling lambat satu tahun sejak berlakunya Undang-Undang Pajak Daerah dan Retribusi Daerah tersebut yaitu 31 Desember 2010.

Kinerja adalah hasil atau tingkat keberhasilan seseorang secara keseluruhan selama periode tertentu dalam melaksanakan tugas, seperti standar hasil kerja, target atau sasaran atau kriteria yang ditentukan terlebih dahulu telah disepakati bersama (Siagian, 2005 : 67). Kinerja sebagai suatu keseluruhan kemampuan untuk bekerja sedemikian rupa sehingga mencapai tujuan kerja secara optimal dan berbagai sasaran yang telah diciptakan dengan pengorbanan yang secara rasio lebih kecil dibandingkan dengan hasil yang dicapai. Kinerja pegawai kecamatan Sukra Kaupaten Indramayu sangatlah memprihatinkan, karena kurangnya pengertian dan kesadaran masyarakat akan kewajibannya membayar BPHTB. Karena kurangnya penyuluhan dari aparat yang berwenang juga tingkat intelektual masyarakat pedesaan yang minim, tidak mempunyai kesadaran dalam membayar BPHTB. Karena kemiskinan dan pelaksanaan pemungutan itu sendiri yang juga banyak menemui hambatan yang disebabkan 
kurangnya kesadaran para aparat berwenang dalam kewajibannya untuk melakukan pemungutan pajak.

Sesuai dengan penjelasan Pasal 10 ayat 1 Undang-Undang No.20 Tahun 2000 tentang BPHTB yang menentukan, bahwa "Sistem Pemungutan Bea Perolehan Hak Atas Tanah dan Bangunan adalah Self Assessment, dimana Wajib pajak diberi kepercayaan untuk menghitung dan membayar sendiri pajak yang terhutang dengan menggunakan Surat Setoran Bea Perolehan Hak Atas Tanah dan Bangunan (SSB) dan melaporkannya tanpa berdasarkan diterbitkannya Surat Ketetapan Pajak."

Hasil wawancara penulis dengan Petugas Pembuat Akta Tanah Sementara (PPATS) mengenai langkah yang dilaksanakan dalam memungut Pajak BPHTB di Kecamatan Sukra sebagai berikut:

Langkah yang dilakukan oleh petugas Penglola PPATS dalam memungut pajak BPHTB yaitu :

1. Terlebih dahulu kita lihat dari NJOP yang akan dialihkan haknya, apakah NJOP pada transaksi tersebut melibihi dari Nilai Jual Objek Pajak Tidak Kena Pajak (NJOPTKP) tidak:

2. Kebanyakan wajib pajak tidak memiliki NPWP, sehingga kita siasati dengan menggunakan NPWP petugas pengelola BPHTB;

3. Menjelaskan besaran pajak yang harus dibayar oleh wajib pajak sejelas mungkin;

4. Menjelaskan proses dan prosedur yang harus ditempuh oleh wajib pajak.

Peningkatkan pelayanan yang memuaskan masyarakat sudah menjadi keharusan bagi pemerintah untuk menyediakan dan memberikan pelayanan yang berkualitas kepada masyarakat. Hal tersebut merupakan salah satu bentuk fungsi pokok pemerintahan yaitu memberikan pelayanan (service delivery) selain pembangunan (development) dan pemberdayaan masyarakat (empowerment), (Rasyid, 2007:71). Dalam suatu organisasi harus ada uraian tugas yang jelas, diharapkan setiap orang akan memahami dan menerima tugas yang ditetapkan baginya, sehingga dapat dan mau melaksanakan tugasnya dengan baik. Salah satu hal yang penting yang harus dimiliki oleh seorang pegawai yang sehat adalah kejelasan batas setiap wewenang dan tanggungjawab. Pokoknya apa yang biasa disebut sebagai "job discriptions". Hal ini sangat penting tidak saja dalam struktur birokrasi, tetapi terlebih pada tugas orangorangnya. Jangan heran kalau melihat banyak pegawai yang menganggur di kantorkantor. Itu bukan karena malas, tetapi karena batas pekerjaannya tek pernah jelas.

Dalam proses pengalihan BPHTB, akan terdapat beberapa kendala, baik yang bersumber dari kekurangsiapan pemerintah daerah. Kendala yang timbul perlu mendapat penanganan segera dan dicarikan pemecahannya untuk kelancaran pemungutan pajak daerah. Pemerintah harus lebih siap melayani wajib pajak yang dalam pelaksanaan pembayaran BPHTB. Apabila pemerintah tidak siap, wajib pajak akan beranggapan masih kurangnya tingkat peraturan yang ada di pemerintahan dan wajib pajak nantinya akan malas untuk membayar kewajiban BPHTB nya. Dan juga Wajib Pajak butuh perealisasian atas apa yang mereka berikan kepada pemerintah 
berupa kelengkapan sarana prasarana kepentingan umum yang ada di Kecamatan Sukra Kabupaten Indramayu.

Jadi berdasarkan uraian di atas dapat disimpulkan bahwa Kinerja Pejabat dan PPATS yang dilihat dari kualitas masih dominan rendah, sedangkan dilihat dari segi wajib pajak yaitu kesadaran wajib pajak dalam membayar pajak masih sangat rendah dilihat dari pelaksanaan pemungutan antara wajib pajak dengan petugas pajak yang melaksanakan pemungutan.

\section{Kuantitas dalam Pembangunan}

Pelaksanaan otonomi daerah suatu langkah untuk pelaksanaan pembangunan secara keseluruhan, dimana suatu daerah mempunyai kesempatan untuk mengelolah, mengembangkan, dan membangun daerahnya sendiri sesuai dengan kebutuhan dan potensi yang dimiliki oleh setiap masing-masing daerah. Pelaksanaan pembangunan tidak lain merupakan suatu proses yang berlangsung secara sadar, terencana, dan berkelanjutan dengan sasaran utamanya adalah untuk meningkatkan kesejahteraan hidup masyarakat suatu bangsa. Sebagai daerah otonom, daerah mempunyai wewenang dan tanggung jawab dalam menyelenggarakan kepentingan masyarakat didasarkan atas pertimbangan bahwa daerah lebih mengetahui kebutuhan dan potensipotensi yang ada di daerahnya. Salah satu masalah yang sering dihadapi oleh pemerintah daerah dalam penyelenggaraan dan pembangunan adalah terhambatnya sumber pembiayaan pembangunan yang berasal dari Pendapatan Asli Daerah (PAD).

Kabupaten Indramayu sudah menerbitkan Peraturan Daerah Kabupaten Indramayu Nomor 18 Tahun 2010 tentang Bea Perolehan Hak Atas Tanah dan Bangunan Kabupaten Indramayu. Menurut Pasal 3 Peraturan Daerah Kabupaten Indramayu Nomor 18 Tahun 2010 adalah Subjek Pajak Bea Perolehan Hak atas Tanah dan Bangunan adalah orang pribadi atau Badan yang memperoleh Hak atas Tanah dan/atau Bangunan. Wajib Pajak Bea Perolehan Hak atas Tanah dan Bangunan adalah orang pribadi atau badan yang memperoleh hak atas Tanah dan / atau Bangunan.

Keterbatasan SDM yang dimiliki oleh Kantor Kecamatan Sukra, membuat pihak Kecamatan Sukra untuk membuat sebuah inovasi untuk memotivasi petugas PPATS dalam meningkatkan kinerja personal maupun organisasinya. Upaya dan inovasi yang dilakukan oleh Kecamatan Sukra guna untuk meningkatkan mutu dan kualitas SDM petugas PPATS Kecamatan Sukra, selalu diikutsertakan kedalam pelatihan-pelatihan, penataran ataupun pendidikan yang sesuai dengan bidang tugasnya. Dengan adanya upaya inovasi tersebut, petugas PPATS akan mendapat ilmu baru dan pengalaman baru yang sesuai dengan bidang tugasnya. Pemerintah Kabupaten Indramayu menyadari penting dan beratnya tugas dari petugas PPATS, oleh sebab itu petugas PPTAS Kecamatan Sukra dalam menjalankan tugasnya diperkuat atau memiliki payung hukum yaitu Peraturan Daerah Kabupaten Indramayu Nomor 18 Tahun 2010 tentang Bea Perolehan Hak Atas Tanah dan Bangunan Kabupaten Indramayu. Karena dalam Perda tersebut ada rincian tugas dan SOP jelas dalam menjalankan tugas, jika rincian tersebut sudah ada maka saat terjadi penyimpangan bisa lebih mudah mencari siapa yang bertanggungjawab. 
Tidak tercapainya penerimaan pajak BPTHB di Kecamatan Sukra, banyak wajib pajak yang tidak memiliki kesadaran dalam membayar pajak. Upaya menghindar pajak juga merupakan kendala yang sangat umum terjadi, kecenderungan wajib pajak untuk melakukan manipulasi data transaksi jual beli atas tanah dan/atau bangunan yang berdampak pada pengurangan atau bebas pengenaan pajak BPHTB. Hal ini terjadi apabila harga pasar atau nilai transaksi lebih tinggi dari Nilai Jual Objek Pajak (NJOP), maka mereka akan menyampaikan bahwa harga transaksi sesuai dengan NJOP. Demikian juga apabila nilai objek pajak lebih rendah dari Nilai Jual Objek Pajak, masyarakat akan berusaha menghindarnya. Sehingga dasar pengenaan BPHTB tidak lagi Nilai Perolehan Objek Pajak (NPOP), melainkan Nilai Jual Objek Pajak (NJOP) .

Dalam transaksi di desa terpencil, tanah yang diperjual belikan luas namun harga jualnya sedikit tidak sampai 60 juta, sehingga dapat terhindar dari pajak. Adanya wajib Pajak yang tidak melaporkan perbuatan hukum yang mengakibatkan peralihan hak ke Kantor Kecamatan, sehingga pejabat terkait tidak dapat melacaknya. Indikator kinerja harus merupakan suatu yang akan dihitung dan diukur serta digunakan sebagai dasar untuk menilai atau melihat tingkat kinerja baik dalam tahap perencaanaan, pelaksanaan maupun setelah kegiatan selasai dan berfungsi. Indikator kinerja digunakan untuk menyakinkan bahwa kinerja hari demi hari organisasi atau unit kerja yang bersangkutan menunjukkan kemampuan dalam rangka atau menuju tujuan dan sasaran yang telah ditetapkan (Sedarmayanti, 2001:198)

Demikian pula dalam hal pekerjaan, sikap kooperatif sangat dibutuhkan pegawai untuk mendukung pekerjaannya, karena dalam setiap pekerjaan terlebih yang berhubungan dengan orang banyak, antar pegawai perlu kerjasama yang baik, karena pada dasarnya dalam pekerjaan didalamnya terdapat tim, yang dibentuk formal dan informal, yang harus didasari rasa kerjasama agar tujuan dari pekerjaan dapat tercapai sesuai rencana. Begitu juga dengan petugas PPATS kecamatan yang dalam pelaksanaan pekerjaannya sangat berkaitan dengan pihak lain yang saling memiliki kepentingan mengenai Pajak BPHTB di Kecamatan Sukra. petugas PPATS kecamatan harus dan wajib memiliki sikap kooperatif yang didasarkan dari dalam dirinya untuk melaksanakan tugasnya, terlebih petugas PPATS memiliki target dalam pekerjaannya, dimana target tersebut tidak bisa tercapai jika hanya dikerjakan oleh kolektor dan koordinator. Selain itu juga harus didukung oleh pemegang kepentingan dan kekuasaan yang ada di wilayah Kecamatan Sukra.

\section{Penggunaan Waktu Dalam Bekerja}

Pajak merupakan salah satu instrumen penting dari pendapatan yang di terima oleh negara. Seperti halnya yang tertuang dalam pembukaan UUD (Undang-Undang Dasar) 1945 bahwa negara harus menjamin kesejahteraan rakyat Indonesia. Dilatar belakangi dengan hal ini maka pemerintah berkewajiban mengelola dan menjaga segala sesuatu yang berkaitan dengan hajat hidup warga negara indonesia seperti halnya yang di terangkan dalam pembukaan UUD (Undang-Undang Dasar) 1945. Dalam hal ini tanah, air dan sumberdaya alam lainya yang dapat menopang kesejahteraan rakyat.Tanah bereta bangunan yang berada dalam wilayah teritori negara menjadi 
objek dalam pemungutan Pajak Bea Perolehan Hak Atas Tanah dan Bangunan (BPHTB). Seperti yang tertuang dalam undang-undang Nomor 28 Tahun 2007 yang menyatakan bahwa pajak merupakan kontribusi wajib kepada negara yang terutang oleh orang pribadi atau badan yang bersifat memaksa bedasarkan undang-undang, dengan tidak mendapatkan imbalan secara langsung dan di gunakan untuk keperluan negara sebesar-besarnya bagi kemakmuran rakyat. Hal ini jelas bahwasanya peranan pemerintah dalam mengoptimalisasikan pajak perlu, guna kemakmurkan rakyat dan membangun negara.

Bea Perolehan Hak Atas Tanah dan Bangunan (BPHTB) merupakan pajak yang dikenakan atas perolehan hak atas tanah dan atau bangunan. Perolehan Hak Atas Tanah dan Bangunan adalah perbuatan atau peristiwa hukum yang mengakibatkan diperolehnya hak atas tanah dan atau bangunan oleh orang pribadi atau badan. Pajak yang dikenakan atas tanah dan bangunan ini atau BPHTB ini bersifat wajib bagi Wajib Pajak yang mempunyai tanah dan bangunan.Mengenai terdapat pada Keputusan Mentri Keuangan No.516/KMK04/2004. Sejak tanggal 01 Januari 2011 Bea Perolehan Hak Atas dan Bangunan (BPHTB) kewenangan pemungutannya dialihkan oleh Pemerintah Pusat ke Pemerintah Daerah yang diatur berdasarkan Undang-Undang Nomor 28 Tahun 2009 tentang Pajak Daerah dan Retribusi Daerah. Pajak provinsi terdiri dari pajak kendaraan bermotor, bea balik nama kendaraan bermotor, pajak air permukaan, dan pajak rokok. Pajak kabupaten/kota terdiri dari pajak hotel, pajak restoran, pajak hiburan, pajak reklame, pajak penerangan jalan, pajak mineral bukan logam dan batuan, pajak parkir, pajak air tanah, pajak sarang burung walet, pajak bumi dan bangunan perdesaan dan perkotaan, dan Bea Perolehan Hak Atas Tanah dan Bangunan (BPHTB). Pelaksanaan pemungutan pajak daerah adalah merupakan kegiatan untuk mengumpulkan iuran wajib yang dilakukan oleh orang pribadi atau badan kepada daerah yang dapat dipaksakan berdasarkan peraturan perundangundangan yang berlaku dengan melalui tahapan-tahapan yang terdiri dari pendataan wajib pajak daerah, pemungutan pajak daerah hingga kuantitas dan kualitas aparat pemungut pajak daerah serta faktor penghambat terhadap hasil kerja pelaksanaan dalam pelaksanaan pemungutan pajak daerah.

Pelaksanaan pemungutan pajak adalah proses implementasi atau proses kebijakan yang hanya dapat dimulai apabila tujuan-tujuan dan sasaran yang semua telah ditetapkan, Secara sederhana, tujuan pelaksanaan pemungutan adalah untuk menetapkan agar tujuan-tujuan kebijakan pemerintah dapat dilaksanakan. Keberhasilan atau kegagalan dalam pelaksanaan dapat ditinjau dari sudut kemampuannya secara nyata dalam pelaksanaan yang telah dirancang sebelumnya (Siagian, 2005 : 69). Pelaksanaan pemungutan BPHTB adalah Self Assessment System yang didasarkan atas adanya transaksi jual beli tanah dan bangunan yang disebabkan adanya peralihan hak atas tanah dan bangunan oleh orang pribadi atau badan dilakukan sesuai dengan ketentuan yang terdapat dalam Pasal 1 angka (4) UndangUndang Nomor 28 Tahun 2009 tentang Pajak Daerah dan Retribusi Daerah. Bagi pihak yang menerima peralihan hak atas tanah dan/atau bangunan dikenakan kewajiban dalam pembayaran pajak Bea Perolehan Hak Atas Tanah dan Bangunan (BPHTB) 
sesuai dengan jumlah yang ditentukan oleh Undang-undang. Setiap undang-undang pajak harus menetukan dengan jelas kapan saat dan tempat pajak terutang, sehingga tidak menimbulkan permasalahan di kemudian hari. Dalam hal perolehan hak atas tanah dan/bangunan saat yang menentukan pajak terutang adalah pada saat ditandatanganinya akta peralihan hak atas tanah dan/atau bangunan yang dibuat di hadapan PPAT/Notaris. Penandatanganan ini sangat penting karena merupakan suatu bukti akta otentik. Akta PPAT wajib dibuat sedemikian rupa sehingga dapat dijadikan dasar yang kuat untuk pendaftaran pemindahan hak dan pembebanan hak yang bersangkutan.

Sementara itu di Kecamatan Sukra yang mengesahkan akta jual beli adalah Pejabat Pembuat Akta Tanah Sementara (PPATS) Kecamatan Sukra harus mengikuti aturan yang berlaku, di mana penyetoran pajak Bea Perolehan Hak atas Tanah dan Bangunan (BPHTB) harus dilakukan verifikasi terhadap kelengkapan dokumen dan kebenaran data terkait objek pajak yang tercantum dalam Surat Setoran Pajak Daerah BPHTB sebelum wajib pajak melakukan pembayaran BPHTB terutang oleh Dinas Pendapatan Pengelolaan Keuangan dan Aset Daerah

Undang-Undang Bea perolehan Hak atas Tanah dan Bangunan (BPHTB) menentukan berapa pejabat yang berwenang dalam pemenuhan ketentuan BPHTB atas suatu perolehan hak atas tanah dan bangunan. Para pejabat ini diberi kewenangan untuk memeriksa apakah Bea Perolehan Hak atas Tanah dan Bangunan (BPHTB) terhutang sudah disetor ke Kas Daerah, oleh pihak yang memperoleh hak sebelum pejabat yang berwenang menandatangani dokumen yang berkenaan dengan perolehan dimaksud.

Berikut hasil wawancara penulis dengan Camat Sukra tentang Penggunaan waktu yang dilaksanakan oleh Petugas PPATS dalam memungut Pajak BPHTB, sebagai berikut : Waktu pemungutan BPHTB berlangsung pada hari kerja (Senin-Jumat) pada hari kerja. Waktu pemungutan BPHTB dilakukan setelah ada transaksi jual beli tanah dan/atau bangunan dan melakukan akta jual beli (AJB) yang dilakukan oleh Pejabat PPATS. Untuk penentuan besarnya pajak BPHTB dilakukan dulu verifikasi pembayaran BPHTB yang dilakukan pejabat pejabat Pajak pada Badan Keuangan Daerah Kabupaten Indramayu. Berdasarkan wawancara di atas dapat disimpulkan bahwa Pejabat PPATS apabila mereka melakukan pengalihan hak atas tanah dalam menentukan besarnya Bea Perolehan Hak atas Tanah dan Bangunan (BPHTB) mengadakan penghitungan sendiri sesuai dengan harga kesepakatan antara penjual dan pembeli, yaitu besarnya pajak terhutang adalah 5\% x (Nilai Perolehan Obyek Pajak - Nilai Perolehan Obyek Pajak Tidak Kena Pajak), di mana Nilai Perolehan Obyek Pajak Tidak Kena Pajak (NPOPTKP) ditentukan secara regional tiap-tiap daerah, untuk Kabupaten Indramayu sebesar Rp 60.000.000,-. Berhasil atau gagalnya pelaksanaan fungsi-fungsi tersebut sangat bergantung pada sejauh mana kualitas yang dimiliki oleh manusia itu sebagai tenaga kerja. Salah satu unsur pelaksana kegiatan pemungutan pajak BPHTB dan menjadi ujung tombak di kecamatan adalah petugas pengelola PPATS. Kualitas dari petugas pengelola BPHTB sangat menentukan kinerja kecamatan dalam pemungutan pajak BPHTB. Dengan adanya petugas pengelola PPATS yang 
berkualitas, maka kecamatan dapat mencapai target pajak BPHTB akan optimal. Tercapainya tujuan kecamatan hanya dimungkinkan karena adanya upaya petugas pengelola PPATS yang ada di kecamatan tersebut. Dalam hal ini terdapat hubungan erat antara kinerja perorangan dengan kinerja kecamatan secara keseluruhan. Dengan demikian, kinerja petugas pengelola PPATS merupakan hal yang sangat penting dalam pencapaian tujuan kecamatan dalam pencapaian target pajak BPHTB.

Keluhan yang muncul beranekaragam, mulai dari kurangnya pemahaman tugas pokok dan fungsi pejabat PPATS, administrasi dalam pemungutan BPHTB masih belum tertib, dan sikap dari pengelola PPATS yang mengabaikan kepentingan masyarakat. Apabila kondisi seperti ini dibiarkan, maka akan berdampak buruk bagi kinerja Pejabat dan pengelola PPTAS itu sendiri dan lebih jauh lagi akan mempengaruhi terhadap menurunnya kinerja kecamatan secara keseluruhan. Oleh karena itu, untuk mewujudkan pejabat dan pengelola PPATS yang memiliki kinerja yang tinggi, diperlukan adanya upaya perbaikan dalam menunjang pelaksanaan pekerjaan baik secara individu maupun yang dilakukan oleh pihak kecamatan.

Verifikasi lapangan ini di karenakan pihak Badan Keuangan Daerah Kabupaten Indramayu tidak percaya atas apa yang telah di lakukan oleh wajib pajak dalam perhitungan bea perolehan hak atas tanah dan bangunan. Di karenakan Badan Keuangan Daerah Kabupaten Indramayu merasa atau berpendapat bahwa harga transaksi atas objek pajak tersebut terlalu rendah.

Untuk meningkatkan penerimaan pajak tidaklah mudah, perlu adanya tindakan sosialisasi dari Pemerintah Daerah kepada masyarakat agar masyarakat mengenal dan mengerti mengenai pajak BPHTB. Sosialisasi dapat dilakukan melalui media cetak yaitu ajakan kepada masyarakat tentang pentingnya membayar pajak dan memberikan pengetahuan mengenai $\mathrm{BPHTB}$, misalnya mekanisme pembayaran BPHTB, dasar pengenaan BPHTB, objek pajak BPHTB, dan lain-lain, Selain itu melalui media cetak juga bisa mencantumkan target dan realisasi BPHTB selama beberapa tahun terakhir agar masyarakat mengetahui bagaimana penerimaan BPHTB di Kabupaten Indramayu, dengan melihat hasil penerimaan BPHTB khususnya pada tahun yang tidak mencapai target, maka masyarakat menilai bahwa ada masalah dalam penerimaan dan ada kemungkinan timbul kesadaran Wajib Pajak dalam membayar kewajiban. Sosialisasi sebaiknya tidak hanya dilakukan melalui media cetak, tetapi juga dilakukan melalui media online karena mengingat banyak masyarakan yang menggunakan smartphone. Selain itu sosialisasi juga bisa dilakukan dengan tatap muka secara langsung kepada masyarakat, sosialisasi seperti ini perlu dilakukan karena tidak semua masyarakat mempunyai smartphone untuk mengakses informasi yang berbasis online seperti masyarakat di pedesaan yang terkadang masih belum mengerti teknologi. Dengan sosialisasi seperti ini masyarakat akan lebih terbantu pemahamannya mengenai pajak BPHTB dan manfaatnya bagi pembangunan daerah.

\section{Penguatan Kerjasama Dalam Bekerja}

Peranan pajak dalam pembangunan terasa sangat penting, sebab dana yang dipergunakan untuk membangun bangsa Indonesia sebagian besar dibiayai dari 
pendapatan pajak. Oleh sebab itu dari tahun ke tahun pemerintah terus berupaya untuk mengoptimalkan pemasukan pajak. Guna mendukung tujuan tersebut perlu adanya peraturan yang mendukung agar realisasi penerimaan pajak dapat tercapai. Pajak sangat besar artinya, karena peranannya dapat menunjang pertumbuhan ekonomi. Untuk itu pemerintah berupaya meningkatkan penerimaan pajak, salah satunya melalui reformasi kebijakan perpajakan. Perubahan kebijakan tersebut (peraturan perundang-undangan perpajakan) mengatur sistem perpajakan secara menyeluruh yang sejalan dengan perkembangan perekonomian saat ini dan di masa yang akan datang. Dalam pembiayaan pembangunan suatu daerah, pemerintah daerah membutuhkan pajak sebagai salah satu sumber penerimaan daerah. Dengan adanya pemberian otonomi daerah kepada pemerintah daerah dan di keluarkannya UndangUndang Nomor 32 Tahun 2004 tentang Pemerintah Daerah dan Undang-Undang Nomor 33 Tahun 2004 tentang perimbangan keuangan antara Pemerintah Pusat dan Daerah memberikan lebih banyak kewenangan kepada daerah dalam menjalankan fungsi pemerintahan dan untuk mengatur sumber-sumber penerimaan daerah sebagai wujud pelaksanaan otonomi daerah.

Pajak mempunyai peranan yang dominan terhadap penerimaan negara dalam negeri dari tahun ketahun yang semakin meningkat. Oleh karena itu peran penerimaan pajak dalam mengisi Kas Pemerintah dalam rangka melanjutkan pembangunan amat penting dan sangat strategis. Besarnya peranan pajak yang demikian kiranya perlu ditanamkan dalam diri setiap orang agar dalam pelaksanaan pembayaran pajak yang telah dilakukan menjadi satu kebanggaan tersendiri karena telah memberikan kontribusinya dalam pembangunan di daerahnya. Pemungutan pajak yang dilakukan oleh pemerintah tidak semata-mata untuk keperluan pemerintah disatu pihak, tetapi demi kepentingan rakyat banyak karena pajak merupakan pungutan yang dilakukan oleh pemerintah tanpa adanya kontraprestasi langsung kepada masyarakat kepada pemerintah. Pemungutan pajak yang dilakukan pemerintah, dilaksanakan sedemikian rupa agar tidak merugikan masyarakat. Oleh karena itu diperlukan syarat-syarat yang khusus untuk melakukannya agar seimbang antara masyarakat dan pemerintah sehingga tidak ada pihak yang dirugikan (Waluyo dan Wirawan, 2013 : 46).

Dari berbagai jenis pajak yang dikenakan terhadap masyarakat di Indonesia sebagaimana dikemukakan tersebut di atas, salah satu pajak yang dikenakan akibat terjadinya perbuatan hukum atau peristiwa hukum atas peralihan hak atas tanah dan/ atau bangunan adalah Bea Perolehan Hak Atas Tanah dan Bangunan (BPHTB).

Menurut Ismawan (2011 : 15) mengemukakan bahwa BPHTB harus dibayar apabila melakukan salah satu hal berikut ini :

1. Akta pemindahan hak atas tanah atau bangunan di tanda tanganin oleh Risalah Lelang, untuk lelang ditanda tangani oleh Kepala Kantor Lelang atau Pajabat Lelang yang berwenang.

2. Dilakukannya pendaftaran hak kepada Kantor Pertanahan Kabupaten atau Kotamadya dalam hal pemberian hak baru atau pemindahan hak baru atau pemindahan hak karena pelaksanaan putusan hakim atau wasiat. 
Subjek Pajak Bea Perolehan Hak Atas Tanah dan/atau Bangunan adalah orang pribadi atau badan yang memperoleh hak atas tanah dan/atau bangunan. Wajib Pajak adalah orang pribadi atau badan yang meliputi pembayaran, pemotongan pajak dan pemungutan pajak, yang mempunyai hak dan kewajiban perpajakan sesuai dengan ketentuan peraturan perundang-undangan perpajakan.

Perolehan Hak atas Tanah dan Bangunan yang dibayar oleh wajib pajak. Oleh karena itu, banyak Wajib Pajak mengunakan dasar pengenaan Bea Perolehan Hak atas Tanah dan Bangunan (BPHTB) yang dipakai adalah dengan mengaju pada Nilai Jual Objek Pajak (NJOP) yang tercantum dalam Surat Pemberitahuan Pajak Terhutang (SPPT). Realisasi penerimaan pajak BPHTB di Kecamatan Sukra selama ini belum mencapai terget yang diinginkan disebabkan karena pemungutan belum dilaksanakan seoptimal mungkin. Tidak kesadaran dari wajib pajak untuk memberikan keterangan yang jujur tentang nilai transaksi yang terjadi di lapangan dan juga masyarakat yang sulit untuk disadarkan merupakan masalah yang sangat dirasakan sekali dalam prakteknya melakukan pemungutan. Berikut adalah hasil wawancara penulis dengan petugas pengeola PPTAS Kecamatan Sukra memberikan jawaban sebagai berikut: Kerjasama antara wajib pajak dengan petugas pengelola PPATS di Kecamatan Sukra yaitu tidak berinteraksi secara langsung dengan wajib pajak, karena wajib pajak kebanyakan membayar langsung melalui Petugas Desa. Dari segi kesadaran masyarakat juga masih ada beberapa yang melaporkan transaksi berdasarkan NJOP, tetapi kedepannya mudah-mudahan masyarakat bisa mengerti bahwa yang harus dilaporkan adalah berdasarkan harga transaksi.

Jadi suatu kerja sama tidak akan berjalan efesien apabila tidak pernah diadakannya suatu pantauan apakah kegiatan itu sudah berhasil atau belum. Adanya usaha untuk melihat kendala-kendala apa yang ada dilapangan, adanya pengevaluasian dan pengarahan adalah merupakan hal-hal yang harus dilakukan dalam hal melakukan pemantauan atau monitoring yang diadakan oleh pimpinan khususnya Camat Kecamatan Sukra, sebab hal ini dirasakan kurang berhasil apabila salah satu kegiatan ini tidak dilaksanakan. Sebab tujuan yang ingin dicapai adalah untuk mencapai pengoptimalan penerimaan Pajak BPHTB. Kegiatan ini sekaligus melakukan pembinaan kepada petugas secara langsung bagaimana memecahkan kendala-kendala yang ada untuk kemudian turun memungut pajak.

Pencapaian suatu tujuan tidak terlepas dari adanya kerja sama yang baik antara sesama pihak yang terkait. Oleh karena itu pihak Kecamatan Sukra juga menjalin hubungan baik dengan seluruh pihak-pihak yang terkait, dalam kelancaran pemungutan pajak BPHTB. Seperti dengan Pejabat PPATS dan Kepala Desa. Secara umum bentuk kerja sama yang dilakukan Kepala Desa dalam membantu atau meningkatkan pembayaran pajak BPHTB adalah dengan memberikan nilai transaksi yang terjadi kepada wajib pajak yang akan melakukan AJB kepada Pejabat PPATS. Menurut Friedrich dalam Winarno (2007 : 17) dikatakan bahwa Kebijakan sebagai suatu arah tindakan yang diusulkan oleh seseorang, kelompok atau pemerintah dalam suatu lingkungan tertentu yang memberikan hambatan-hambatan dan peluang-peluang terhadap kebijakan yang diusulkan untuk menggunakan dan mengatasi dalam rangka 
mencapai suatu tujuan atau merealisasikan suatu sasaran atau suatu maksud tertentu. Pelaksanaan pemungutan Pajak BPHTB tidak terlepas dari usaha-usaha yang dilakukan oleh Pejabat PPATS, karena syarat untuk dalam proses administrasi penandatangan sebuah akta jual beli oleh PPATS mewajibkan bukti pembayaran kepada wajib pajak, BPHTB untuk menyerahkan bukti pembayaran atau pelunasan pajak BPHTB yang terutang melalui form surat setoran pajak daerah (SSPD BPHTB) dan telah tervalidasi oleh pihak Badan Keuangan Daerah Kabupaten Indramayu.

\section{Kesimpulan}

Berdasarkan hasil penelitian yang penulis lakukan mengenai Kinerja Pejabat Pembuat Akta Tanah Sementara (PPATS) dalam Pengelolaan Bea Perolehan Atas Tanah Atau Bangunan (BPHTB) di Kecamatan Sukra Kabupaten Indramayu belum optimal, dengan deskripsi sebagai berikut; Kualitas Pejabat PPATS khususnya di Kecamatan Sukra dalam pengelolaan BРHTB masih kurang maksimal, itu terlihat dari realisasi yang belum mencapai target yang sudah ditentukan oleh Pemerintah Daerah sesuai dengan potensi yang ada, bahkan untuk target tahun 2015 turun dari realisasi untuk tahun sebelumnya. Kuantitas hasil pekerjaan yang dilaksanakan oleh Pejabat PPATS dalam mengelola BPHTB di wilayah Kecamatan Sukra masih belum efektif karena hasil yang dicapai tersebut belum sesuai target yang telah ditetapkan oleh pemerintah daerah dilihat dari potensi yang ada di wilayah Kecamatan Sukra. Penggunaan waktu yang dilaksanakan oleh Pejabat PPATS di Kecamatan Sukra sesuai dengan jam kerja yaitu dari hari Senin sampai dengan Jum'at. Pemungutan BPHTB dilaksanakan setelah ada transaksi jual beli tanah dan/atau bangunan dan melakukan akta jual beli (AJB) yang dilakukan oleh Pejabat PPATS. Untuk penentuan besarnya pajak BPHTB dilakukan dulu verifikasi pembayaran BPHTB yang dilakukan pejabat pejabat Pajak pada Badan Keuangan Daerah Kabupaten Indramayu. Kerjasama Pejabat PPATS di Kecamatan Sukra dengan masyarakat sudah baik, hanya saja masih banyak masyarakat belum menyadari manfaat Pajak, itu dikarenakan tingkat pendidikan masyarakat di Kecamatan Sukra rata-rata masih rendah ditambah lagi tingkat pengetahuan wajib pajak yang masih kurang

\section{Referensi}

As'ad, Mohammad. 1998. Seri Ilmu Sumber Daya Manusia: Psikologi Industri. Yogyakarta: Liberty

Bastian, Indra, 2001. Akuntansi Sektor Publik di Indonesia, Cetakan Pertama, Yogyakarta, BPFE.

Bernardin \& Russel. 2001. Manajemen Sumber Daya Manusia. Diterjemahkan oleh Bambang Sukoco. Bandung: Armico 
Dwiyanto, Agus.2002. Mewujudkan Good Governance Melalui Pelayanan Publik, Yogyakarta :UGM Press.

Georgopolous dan Tannenbaum. 2005. Efektivitas Organisasi. Jakarta: Erlangga

Gibson. 2004. Organisasi: Perilaku, Struktur, Proses. diterjemahkan oleh Ninuk Adriani. Jakarta: Binarupa Aksara.

Handayaningrat, Soewarno. 2005. Administrasi Pemerintah Dalam Pembangunan. Jakarta: Gunung Agung.

Harsuko, Riniwati. 2011. Mendongkrak Motivasi dan Kinerja: Pendekatan Pemberdayaan SDM. Malang : UB Press

Hasibuan Malayu SP. 2006. Manajeman : Dasar, Pengertian dan Masalah. Jakarta : Bumi Aksara

Hikmawan, M. D. (2014). Politik Perbedaan : Demokrasi dalam Paradoks. Universitas Gdjah Mada.

Hikmawan, M. D. (2017). Pluralisme Demokrasi Politik di Indonesia. Journal of Governance, 2(2), 223-247. https://doi.org/http://dx.doi.org/10.31506/jog.v2i2.2678

Hikmawan, M. D., \& Hidayat, R. (2016). Depoliticisation of Public Issue : Low Degree of Government' S Democratic Legitimacy. Journal of Governance, 1(1), 23-37. https://doi.org/http://dx.doi.org/10.31506/jog.v1i1.1311

Keban, Yeremias T, 2005, Enam Dimensi Strategis Administrasi Publik: Konsep, Teori, dan Isu,. Yogyakarta: Penerbit Gaya Media.

Kurniawan Agung. 2005. Transformasi Pelayanan Publik. Yogyakarta: Pembaruan

Lexy J. Meloeng. 2006. Metode Penelitian Kualitatif. Bandung : PT Remaja Rosdakarya.

Martani dan Lubis. 2007. Manajmen Modern. Jakarta: Rineka Cipta

Peraturan Daerah Kabupaten Indramayu Nomor 18 Tahun 2010 tentang Bea Perolehan Hak Atas Tanah dan Bangunan Kabupaten Indramayu

Riani, Asri Laksmi. 2013. Budaya Organisasi. Yogyakarta: Graha Ilmu.

Rivai Veithzal, 2003, Manajemen Sumber Daya Manusia untuk Perusahaan, Raja Grafindo Persada: Jakarta.

Robbins, Stephen P. 2001. Perilaku Organisasi.. Jakarta: PT Indeks Kelompok Gramedia Ruky Achmad S. 2001, Sistem Manajemen Kinerja, Jakarta : PT. Gramedia Pustaka Utama Sedarmayanti, 2001, Sumber Daya Manusia dan Produktivitas Kerja, Bandung: Mandar Maju.

Siagian P. Sondang. 2006. Manajemen Sumber Daya Manusia. Jakarta: Penerbit Bumi Aksara. 
Simamora, Henry. 1995. Manajemen Sumber Daya Manusia. Yogyakarta; STIE YKPN

Sinambela, Lijan Poltak. 2012. Manajemen Sumber Daya Manusia. Jakarta: PT Bumi Aksara

Steers, Ricard M. 2005. Efektivitas Organisasi. Jakarta: Erlangga

Sudarmanto. 2009. Kinerja dan Pengembangan Kompetensi SDM. Yogyakarta: Pustaka Pelajar

Sugiyono, 2010, Memahami Penelitian Kualitatif, Bandung : Alfabeta.

Suharto dan Budhi Cahyono. 2005. Pengaruh Budaya Organisasi, Kepemimpinan dan Motivasi Kerja Terhadap Kinerja Sumber Daya Manusia di Sekretariat DPRD Propinsi Jawa Tengah. Jurnal Riset \& Bisnis Indonesia, Vol.1, No.1.

Suyanto, Bagong. 2005. Metode Penelitian Sosial: Berbabai Alternatif Pendekatan. Jakarta : Prenada Media

Tangkilisan, Nogi Hessel. 2009. Manajemen Publik. Jakarta : PT. Gramedia Widiasarana Indonesia

Undang-Undang Republik Indonesia Nomor 28 Tahun 2007 Tentang Perubahan Ketiga Atas Undang-Undang Nomor 6 Tahun 1983 Tentang Ketentuan Umum Dan Tata Cara Perpajakan

Undang- undang Nomor 20 tahun 2000 tentang Bea Perolehan Hak atas Tanah dan Bangunan

Undang-Undang Nomor 28 Tahun 2009 tentang Pajak Daerah dan Retribusi Daerah

Wibowo. 2010. Manajemen Kinerja. Jakarta. Penerbit: Rajagrafindo Persada.

Widiyanto, A., Hikmawan, M. D., \& Riswanda, riswanda. (2019). JSPG: Journal of Social Politics and Governance Implementasi Rencana Aksi Nasional Bela Negara Berdasarkan Instruksi Presiden Nomor 7 Tahun 2018 Oleh Dewan Ketahanan Nasional Republik Indonesia. Journal of Social Politics and Governance, 1(2), 95-115.

Wijayanti, Irine Diana Sari. 2008. Manajemen. Yogyakarta: Mitra Cendikia Press 